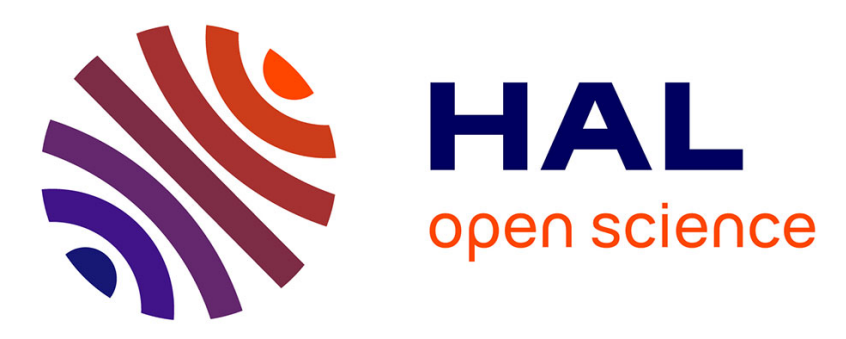

\title{
Kinetics of the Oxidation of N-Aminopiperidine with Chloramine
}

\author{
Chaza Darwich, Mazen Elkhatib, Georg Steinhauser, Henri Delalu
}

\section{To cite this version:}

Chaza Darwich, Mazen Elkhatib, Georg Steinhauser, Henri Delalu. Kinetics of the Oxidation of NAminopiperidine with Chloramine. Kinetics and Catalysis, 2009, 50 (1), pp.103-111. hal-00397533

\section{HAL Id: hal-00397533 \\ https://hal.science/hal-00397533}

Submitted on 22 Jun 2009

HAL is a multi-disciplinary open access archive for the deposit and dissemination of scientific research documents, whether they are published or not. The documents may come from teaching and research institutions in France or abroad, or from public or private research centers.
L'archive ouverte pluridisciplinaire HAL, est destinée au dépôt et à la diffusion de documents scientifiques de niveau recherche, publiés ou non, émanant des établissements d'enseignement et de recherche français ou étrangers, des laboratoires publics ou privés. 


\title{
Kinetics of the Oxidation of N-Aminopiperidine with Chloramine
}

Chaza Darwich $^{1, *}$, Mazen Elkhatib ${ }^{2}$, Georg Steinhauser ${ }^{3}$ and Henri Delalu ${ }^{1}$

1 Laboratoire Hydrazines et Procédés, UMR 5179 CNRS-ISOCHEM (groupe SNPE), Université Claude Bernard Lyon 1, Bâtiment Berthollet, 22 Avenue Gaston Berger, F-69622 Villeurbanne Cedex, France. \{e-mail: aromadervish@yahoo.com; delalu@univ-lyon1.fr, telephone : +33 4 72432664, fax : +33 4 72431291\}.

${ }^{2}$ Laboratory of Applied Chemistry and Toxicology, Faculty of Sciences, Section 3, Department of Chemistry, P.O. Box 826, Tripoli, Lebanon \{e-mail: mazen@ul.edu.lb, telephone : +961 3 490204, fax : +9616386365\}.

3 Vienna University of Technology, Atominstitut der Österreichischen Universitäten, Stadionallee 2, A-1020 Vienna, Austria \{e-mail: georg.steinhauser@ati.ac.at, telephone : +4315880114189, fax : +43158 80114199$\}$

* corresponding author

\begin{abstract}
The kinetics of the oxidation of $\mathrm{N}$-aminopiperidine with chloramine was studied at different temperatures, with variable concentrations of the two reactants and at a $\mathrm{pH}$ ranging between 12 and 13.5. The reaction showed to be involving two steps: the first corresponded to the formation of a diazene intermediate, the second to the evolution of this intermediate into numerous compounds within a complex reactional chain. The rate law of the first step was determined by the Ostwald method and
\end{abstract}


found to be first order with respect to each reactant. The rate constant was determined at $\mathrm{pH}=12.89$ and $\mathrm{T}=25^{\circ} \mathrm{C}$ :

$\mathrm{k}_{2}=1.15 \times 10^{5} \exp (-39 / \mathrm{RT}) \mathrm{M}^{-1} \mathrm{~s}^{-1} \quad\left(\mathrm{E}_{2}\right.$ in $\left.\mathrm{kJ} \mathrm{mol}^{-1}\right)$

With decreasing $\mathrm{pH}$ value, the first step exhibited acid catalysis phenomena, and diazene was converted into azopiperidine particularly faster. This created overlapping UV-absorptions between chloramine and azopiperidine, also observed in HPLC. GC/MS analyses were used to identify some of the numerous by-products formed. Their proportions are dependent of both $\mathrm{pH}$ and the reactants' concentrations ratio. A reaction mechanism taking this relationship into account, was suggested.

\section{Keywords}

Chloramine; Kinetics; N-aminopiperidine; Oxidation; Raschig process

\section{Introduction}

Heterocyclic compounds including an unsymmetrical hydrazine group are used in the pharmaceutical industry as precursors of medicinal drugs. In particular, Naminopiperidine $\left(\mathbf{1}, \mathrm{NAPP}, \mathrm{C}_{5} \mathrm{H}_{12} \mathrm{~N}_{2}\right)$ is a precursor of a selective CB1 endocannabinoid receptor antagonist, commercially known as Rimonabant, which is used for the treatment of obesity and for smoking cessation.

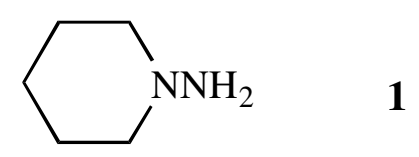

Presently, $\mathbf{1}$ is prepared by different methods, particularly in batch by the two following processes: 
1. The Wright and Willette process [1], which is carried out in two steps (Scheme I):

- nitrosylation of 1-piperidine (PP) by addition of sodium nitrite to an acid solution of the amine (reaction 2)

- reduction of 1-nitrosopiperidine by a chemical or catalytic method (reaction 3)

\section{Scheme I}

(1)

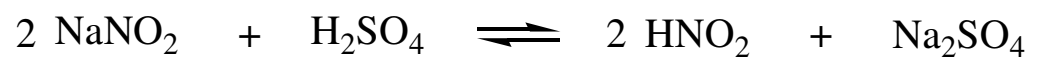

(2)
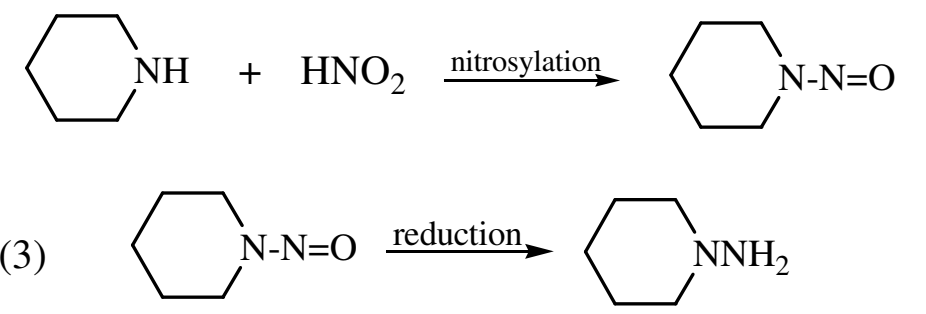

This process leads to a high yield (75 to 92\%) but, before the reduction step, the product of reaction 2 must be purified by distillation or recrystallization. Several methods are possible for its reduction [2-12]. Nevertheless, it must be handled with a lot of precaution because of its highly carcinogenic properties, which complicates synthesis on an industrial scale.

2. The urea method, which includes three steps: the first one is the preparation of 1piperidylurea (reaction 4) followed by chlorination leading to 1-piperidyl-3chlorourea (reaction 5). The latter is finally converted to $\mathrm{N}$-aminopiperidine by addition of a concentrated solution of sodium hydroxide [13-15]. The reaction mechanism is a Hoffmann rearrangement and the yield obtained is about $82 \%$. 
However, this method would hardly be adapted to a continuous synthesis because it involves numerous steps (Scheme II).

Scheme II

(4)

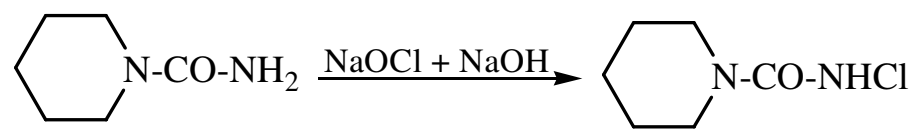

(5)

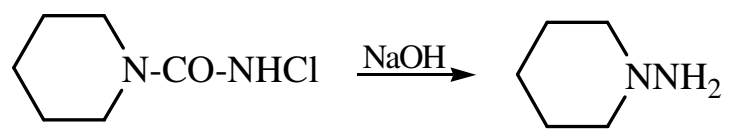

Other methods reported in the literature were also used to prepare 1 [16-18], however many difficulties involving these methods were found. Therefore, to synthesize $\mathbf{1}$ in a high scale we have undertaken an aqueous amination of 1-piperidine by the Raschig process $[19,20]$. This most environmentally-friendly route can be schematized by the following two reactions (Scheme III):

Scheme III

(6) $\mathrm{NaOCl}+\mathrm{NH}_{3} \longrightarrow \mathrm{NH}_{2} \mathrm{Cl}+\mathrm{NaOH}$

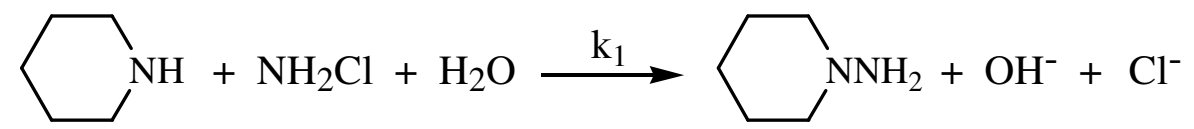

However, it presents the major drawback of leading to numerous by-products. This behavior is particularly due to the simultaneous oxidizing/aminating character of $\mathrm{NH}_{2} \mathrm{Cl}$. In particular, the reaction between $\mathbf{1}$ and chloramine is one of the principal side reactions observed during the synthesis of $\mathbf{1}$ by the Raschig process [21]. This reaction limits the yield and leads to the precipitation of by-products difficult to separate during the continuous extraction of $\mathbf{1}$ [21]. 
In this paper, we report a kinetic study of the monochloramine / $\mathrm{N}$-aminopiperidine reaction.

\section{Experimental}

\section{Reagents}

All reagents and salts used were reagent grade products from ALDRICH $^{\circledR}$ and PROLABO $\mathrm{RP}^{\circledR}$. Water was passed through an ion-exchange resin, then distilled twice, deoxygenated and stored under nitrogen.

$\mathrm{NH}_{2} \mathrm{Cl}$ is unstable in water, it was therefore prepared extemporaneously at $-10^{\circ} \mathrm{C}$ by reacting $25 \mathrm{ml}$ of sodium hypochlorite $2 \mathrm{M}$ and $20 \mathrm{ml}$ of $\mathrm{NH}_{3} / \mathrm{NH}_{4} \mathrm{Cl}$ aqueous solution $\left(\left[\mathrm{NH}_{4} \mathrm{Cl}\right]=2.3 \mathrm{M},\left[\mathrm{NH}_{3}\right]=3.6 \mathrm{M}\right)$ in the presence of diethyl ether $(40 \mathrm{ml})$. The organic layer $\left(0.8-1 \mathrm{M}\right.$ of $\left.\mathrm{NH}_{2} \mathrm{Cl}\right)$ was shaken and washed several times with aliquots of distilled water. Aqueous solution of chloramine was obtained by reextraction from the ethereal phase. Its concentration was determined by UV spectroscopy at $\lambda=243 \mathrm{~nm}\left(\varepsilon=458 \mathrm{M}^{-1} \mathrm{~cm}^{-1}\right)$ [22]. N-aminopiperidine (97\%) was delivered by ALDRICH ${ }^{\circledR}$.

\section{Apparatus}

The apparatus consisted of two thermo-stated vessels of borosilicate glass, one on the top of the other and joined by a conical fitting. The lower reactor $\left(200 \mathrm{~cm}^{3}\right)$ had inlets allowing the measurement of $\mathrm{pH}$ and temperature, influx of circulating nitrogen and removal of aliquots for analysis. Because of the sensitivity of hydrazines to oxidation upon exposure to air, the mixture was monitored by an 
oxygen-sensitive electrode connected to a numerical indicator. The upper cylindrical vessel $\left(100 \mathrm{~cm}^{3}\right)$ was blocked at its base by a solid stopper $(17 \mathrm{~mm}$ i.d.) fastened to a control rod. This set-up allows a quick introduction of the ampoule contents into the reactor and hence a precise definition of the start of the reaction. A slightly reduced pressure was maintained throughout the reaction mixture, and the reactor temperature was kept constant to $\pm 0.1^{\circ} \mathrm{C}$ (thermocouple). A glass electrode (TACUSSEL TB/HS model) and a calomel reference electrode connected to a TACUSSEL ISIS $20000 \mathrm{pH}$ meter were used for $\mathrm{pH}$ measurements.

\section{Results and Discussion}

\section{Procedure and Analysis}

Reactant solutions were prepared at the same $\mathrm{pH}$ (see Experimental): 1 was dissolved in deoxygenated water and introduced into the lower reactor. The $\mathrm{pH}$ value was adjusted by addition of sodium hydroxide and/or a buffer solution. When thermal equilibrium was reached, the aqueous solution of chloramine (prepared according to the above procedure) of identical $\mathrm{pH}$ was added from the upper vessel.

The concentration of chloramine was monitored by making use of its maximum ultraviolet absorption $\left(\varepsilon_{\mathrm{NH}_{2} \mathrm{Cl}}=458 \mathrm{M}^{-1} \mathrm{~cm}^{-1}\right.$ at $\left.\lambda=243 \mathrm{~nm}\right)$. It was analyzed either by UV spectrophotometry using a Cary $1 \mathrm{E}$ double-beam spectrophotometer or by HPLC using a HP 1100 chromatograph equipped with a Diode Array Detector. For experiments monitored by HPLC, the separation was done on a $150 \times 3 \mathrm{~mm}$ ODS XDB- $\mathrm{C}_{8}$ column $\left(\mathrm{d}_{\mathrm{p}}=5 \mu \mathrm{m}\right)$ using $\mathrm{MeOH} / \mathrm{H}_{2} \mathrm{O}(70 / 30)$ as mobile phase (rate flow $=$

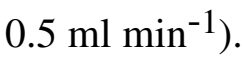


1 is transparent to $\mathrm{UV}$, therefore reaction orders can be easily determined by analyzing the temporal chloramine evolution. In some experiments, aliquots were treated with formaldehyde (40-fold excess) in order to stop the reaction between $\mathrm{NH}_{2} \mathrm{Cl}$ and 1 by converting the latter into its hydrazone (2, FNAPP, $\mathrm{C}_{6} \mathrm{H}_{12} \mathrm{~N}_{2}$ ), which has a maximum absorption in $\mathrm{UV}$ at $237 \mathrm{~nm}\left(\varepsilon_{\mathrm{FNAPP}}=4485 \mathrm{M}^{-1} \mathrm{~cm}^{-1}\right)$. This new method of NAPP derivatization with formaldehyde was recently developed in our laboratory (Scheme IV) [21].

\section{Scheme IV}

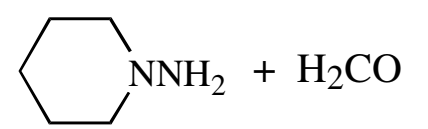

1

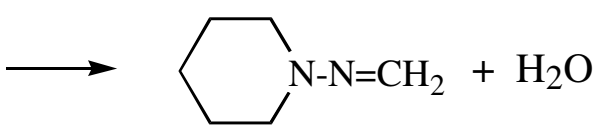

2

GC/MS analyses were carried out on a HP 5890 chromatograph coupled to a mass spectrometer HP 5970 equipped with a 30-m long CP-Sil $\mathrm{C}_{19}$ column $(250 \mu \mathrm{m}$ i.d., $\left.\mathrm{d}_{\mathrm{f}}=1.5 \mu \mathrm{m}\right)$. Methodological details on the apparatus and the experimental procedure have been published previously $[23,24]$.

\section{Characterization of the reaction mixture}

Figure 1 shows a UV spectrophotometric evolution of the mixture at different times of the reaction $\left([\mathrm{NAPP}]_{0}=20 \times 10^{-3} \mathrm{M},\left[\mathrm{NH}_{2} \mathrm{Cl}\right]_{0}=2 \times 10^{-3} \mathrm{M}, \mathrm{pH}=12.89\right.$ and $\mathrm{T}$ $=25^{\circ} \mathrm{C}$ ). In a first step, $\mathrm{NH}_{2} \mathrm{Cl}$ absorption decreased at $243 \mathrm{~nm}$, with the appearance of an isobestic point at $278 \mathrm{~nm}$, which proved that the disappearance of chloramine is simultaneous to the formation of a new product $\mathbf{3}$ also absorbing in UV. Since $\mathbf{1}$ is 
transparent in UV, $\mathbf{3}$ must result from the oxidation of $\mathbf{1}$ by chloramine (see Scheme V).

In a second step, the isobestic point disappeared while UV absorption increased and simultaneously deviated to lower wavelengths. At the end of the second step, the reaction mixture's evolution, monitored by UV spectrophotometry, led to a unique maximum at $237 \mathrm{~nm}$, which is a characteristic wavelength for the absorption of hydrazones.

In order to understand the evolution of compounds in the reaction mixture with respect to the two steps described above, we compare the $\mathrm{C}_{5} \mathrm{H}_{10} \mathrm{NNH}_{2} / \mathrm{NH}_{2} \mathrm{Cl}$ interaction with the ones of $\mathrm{CH}_{3} \mathrm{NHNH}_{2} / \mathrm{NH}_{2} \mathrm{Cl}, \quad\left(\mathrm{CH}_{3}\right)_{2} \mathrm{NNH}_{2} / \mathrm{NH}_{2} \mathrm{Cl}$, $\mathrm{C}_{9} \mathrm{H}_{9} \mathrm{NNH}_{2} / \mathrm{NH}_{2} \mathrm{Cl}$ and $\mathrm{C}_{7} \mathrm{H}_{12} \mathrm{NNH}_{2} / \mathrm{NH}_{2} \mathrm{Cl}$ which have been studied previously [23-25].

We found that the first elementary step of the NAPP oxidation leads transiently to an aminonitrene 3 (diazene intermediate, $\mathrm{C}_{5} \mathrm{H}_{10} \mathrm{~N}_{2}$ ) (Scheme V):

\section{Scheme V}

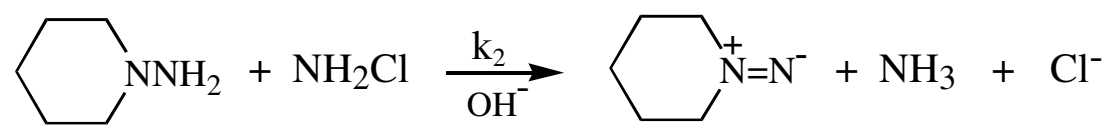




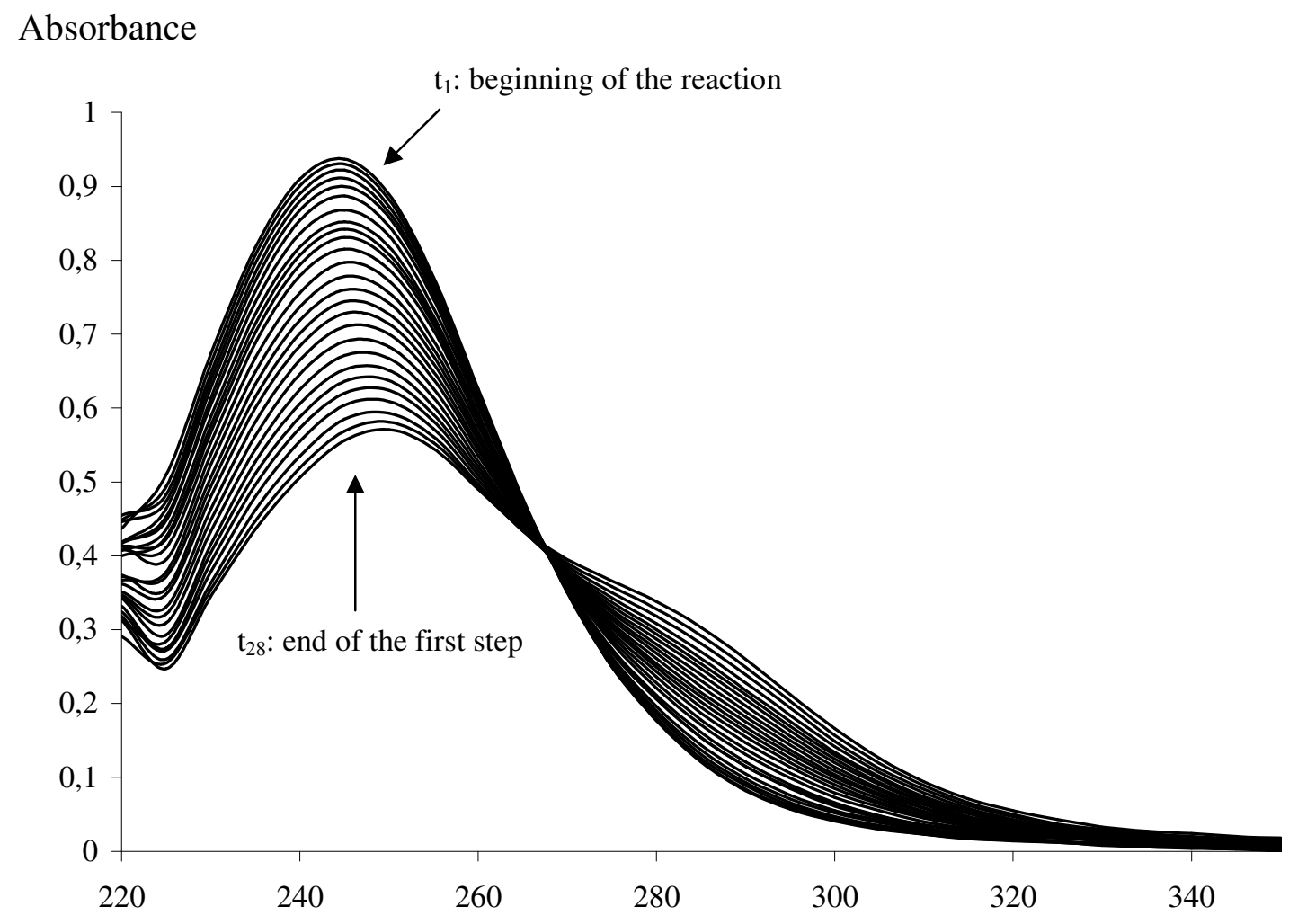

wavelength (nm)

Figure 1. UV absorption spectra of the oxidation of $N$-aminopiperidine with chloramine (first step; $\left[\mathrm{C}_{5} \mathrm{H}_{10} \mathrm{NNH}_{2}\right]_{0}=20 \times 10^{-3} \mathrm{M},\left[\mathrm{NH}_{2} \mathrm{Cl}\right]_{0}=2 \times 10^{-3} \mathrm{M}, \mathrm{pH}=$ 12.89, $\left.T=25^{\circ} \mathrm{C}\right)$.

In the second step, 3 leads to different products (Scheme VI) depending on experimental conditions ( $\mathrm{pH}$, concentration, solvent):

Scheme VI

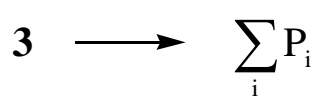

In order to identify these different products, GC/MS analyses were carried out on the reaction mixture (see chromatogram in Figure 2). Numerous peaks were observed, proving that $\mathbf{3}$ is converted to several products within a complex reactional chain. A 
plausible reaction mechanism describing the formation of the most important byproducts is reported later on.

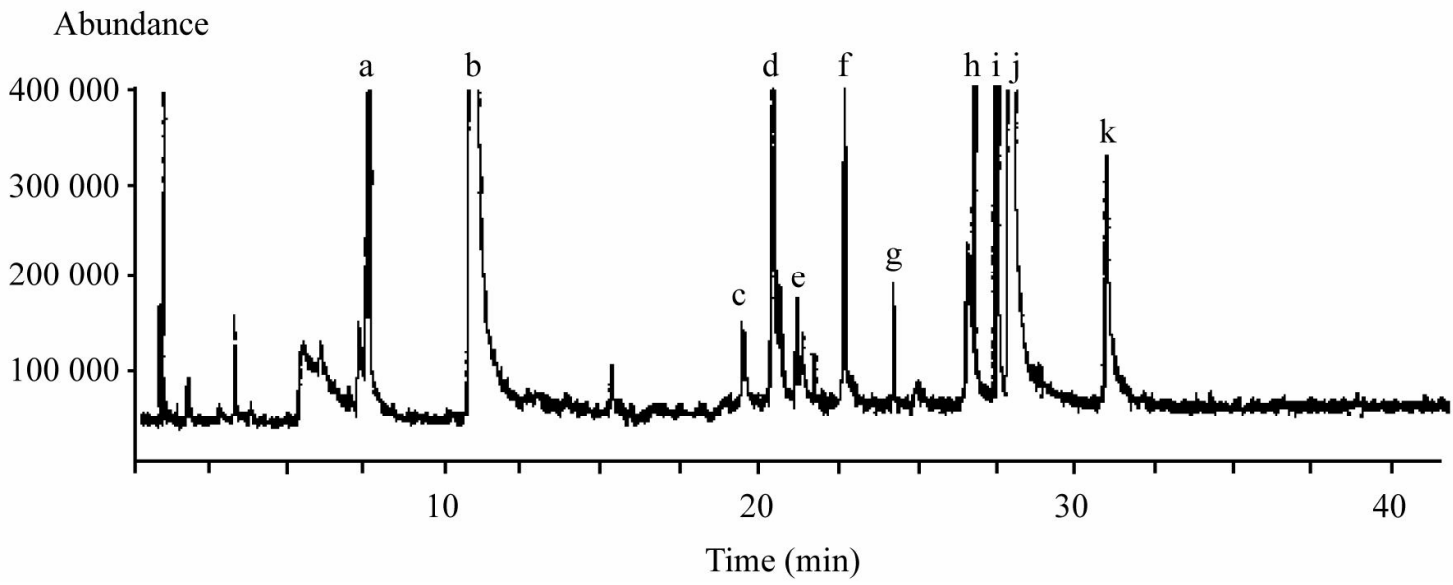

Figure 2. Chromatogram obtained by GC/MS analysis for a $\mathrm{NAPP}-\mathrm{NH}_{2} \mathrm{Cl}$ mixture;

$\left(\left[\mathrm{NH}_{2} \mathrm{Cl}\right]_{0}=2 \times 10^{-3} \mathrm{M},\left[\mathrm{C}_{5} \mathrm{H}_{10} \mathrm{NNH}_{2}\right]_{0}=20 \times 10^{-3} \mathrm{M}, \mathrm{pH}=12.89, \mathrm{~T}=25^{\circ} \mathrm{C}\right)$.

The masses associated to the different peaks observed are as follows:

\begin{tabular}{cc}
\hline Peak & $\mathrm{m} / \mathrm{z}$ \\
\hline $\mathbf{a}$ & 85 \\
$\mathbf{b}$ & 100 \\
$\mathbf{c}$ & 114 \\
$\mathbf{d}$ & 98 \\
$\mathbf{e}$ & 168 \\
$\mathbf{f}$ & 168 \\
$\mathbf{g}$ & 166 \\
$\mathbf{h}$ & 196 \\
$\mathbf{i}$ & 196 \\
$\mathbf{j}$ & 184 \\
$\mathbf{k}$ & 194 \\
\hline
\end{tabular}

Taking previous phenomena into account, the kinetic study of the first step can be established using $\left[\mathrm{NH}_{2} \mathrm{Cl}\right]=\mathrm{f}(\mathrm{t})$. For experiments monitored by UV spectrophotometry, only measurements registered in the first reaction instants were useful to determine $\left[\mathrm{NH}_{2} \mathrm{Cl}\right]$ because the $\mathrm{UV}$ absorption of $\mathbf{3}$ remains negligible in the beginning of the reaction. 
Further experiments were carried out at lower $\mathrm{pH}$ values $(\mathrm{pH} \leq 11.5)$. Under these conditions, the first and second steps appeared to be accelerated. For instance, Figures 3 and 4 show UV absorptions of the reaction mixture with respect to time in two different experiments.

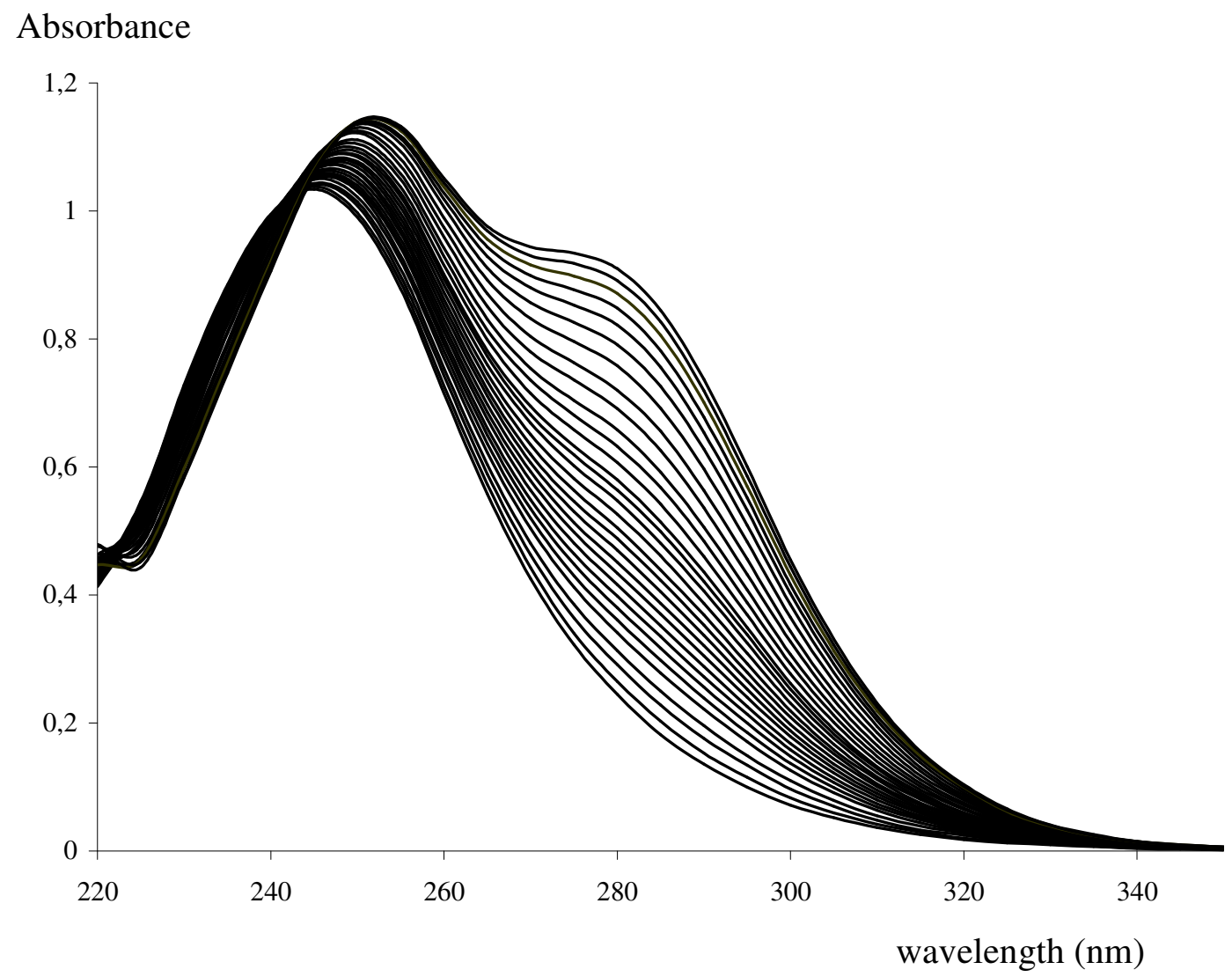

Figure 3. $U V$ absorption spectra of $\mathrm{NAPP}-\mathrm{NH}_{2} \mathrm{Cl}$ mixture at $\mathrm{pH}=11.5$; $\left(\left[\mathrm{C}_{5} \mathrm{H}_{10} \mathrm{NNH}_{2}\right]_{0}=20 \times 10^{-3} \mathrm{M},\left[\mathrm{NH}_{2} \mathrm{Cl}\right]_{0}=2 \times 10^{-3} \mathrm{M}, \mathrm{T}=25^{\circ} \mathrm{C}\right)$. 
Absorbance

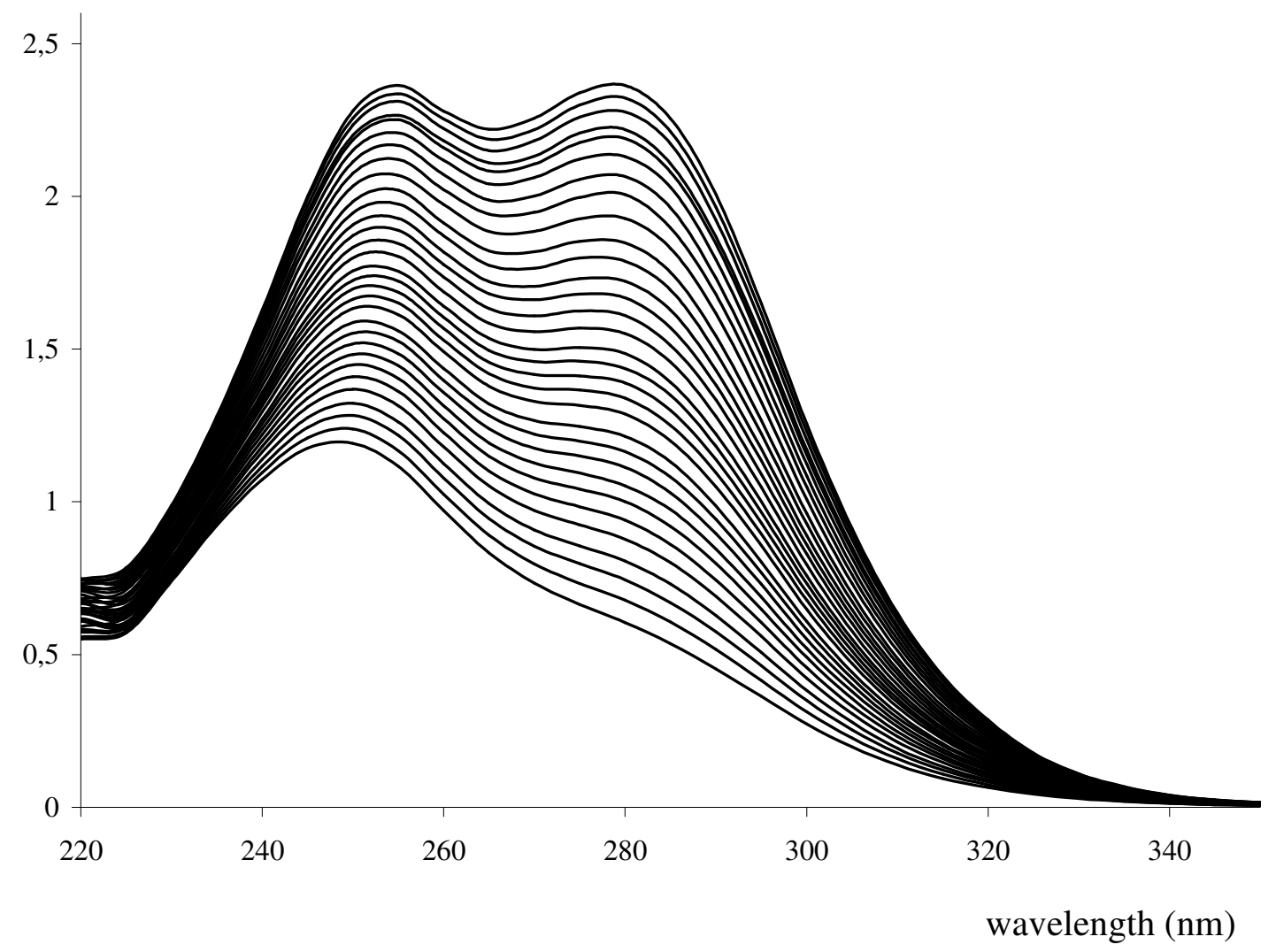

Figure 4. $U V$ absorption spectra of $\mathrm{NAPP}-\mathrm{NH}_{2} \mathrm{Cl}$ mixture at $\mathrm{pH}=11$;

$\left(\left[\mathrm{C}_{5} \mathrm{H}_{10} \mathrm{NNH}_{2}\right]_{0}=20 \times 10^{-3} \mathrm{M},\left[\mathrm{NH}_{2} \mathrm{Cl}\right]_{0}=2 \times 10^{-3} \mathrm{M}, \mathrm{T}=25^{\circ} \mathrm{C}\right)$.

Under these conditions, a kinetic study based on $\left[\mathrm{NH}_{2} \mathrm{Cl}\right]=\mathrm{f}(\mathrm{t})$ and/or $[\mathrm{FNAPP}]=$

$f(t)$ turned out to be impossible because the reactants are completely consumed in less than 3 minutes. Thus, the HPLC method would face limitations for the same reason.

\section{Kinetics of oxidation of $\mathrm{N}$-aminopiperidine with chloramine}

\section{Reaction order and stoichiometry}

Experiments were conducted at $25^{\circ} \mathrm{C}$ with $\mathrm{pH}$ values ranging between 12 and 13.5 (at $\mathrm{pH}$ values below 12, it became impossible to complete the kinetic study for the reasons mentioned above). 
A first series of measurements was performed at $25^{\circ} \mathrm{C}$ and $\mathrm{pH}=12.89$. The kinetic parameters were determined by the Ostwald method and the rate of disappearance of $\mathrm{NH}_{2} \mathrm{Cl}$ may be expressed as follows:

$$
\mathrm{r}=-\mathrm{d}\left[\mathrm{NH}_{2} \mathrm{Cl}\right] / \mathrm{dt}=\mathrm{k}_{2}\left[\mathrm{NH}_{2} \mathrm{Cl}\right]^{\alpha}\left[\mathrm{C}_{5} \mathrm{H}_{10} \mathrm{NNH}_{2}\right]^{\beta}
$$

The stoichiometry of the oxidation of hydrazine with chloramine is $1: 1$ with respect to each reactant [21].

To evaluate $\alpha$, three series of measurements were carried out, using a constant concentration of $1\left(30 \times 10^{-3} \mathrm{M}\right)$ and $\mathrm{NH}_{2} \mathrm{Cl}$ concentrations ranging from $1 \times 10^{-3}$ to $4 \times 10^{-3} \mathrm{M}\left(\mathrm{pH}=12.89, \mathrm{~T}=25^{\circ} \mathrm{C}\right)$. In the first reaction instants, the curves $\mathrm{Log}$ $\left[\mathrm{NH}_{2} \mathrm{Cl}\right]=\mathrm{f}(\mathrm{t})$ came up to be straight lines with the slope $\psi=\mathrm{k}_{2}\left[\mathrm{C}_{5} \mathrm{H}_{10} \mathrm{NNH}_{2}\right]_{0}^{\beta}$ indicating that $\alpha=1$ (Table 1). Similarly, $\beta$ was determined by the same method and under the same conditions by maintaining the concentration of $\mathrm{NH}_{2} \mathrm{Cl}$ constant $\left(1 \times 10^{-3} \mathrm{M}\right)$ and varying the concentration of $\mathbf{1}\left(10 \times 10^{-3}\right.$ to $\left.100 \times 10^{-3} \mathrm{M}\right)$.

Partial orders were also determined from experiments monitored by HPLC (Table 1), and gave the same results as for experiments followed by UV spectrophotometry. Experiments were based on the following initial concentration ratios:

$$
2 \leq\left[\mathrm{C}_{5} \mathrm{H}_{10} \mathrm{NNH}_{2}\right]_{0} /\left[\mathrm{NH}_{2} \mathrm{Cl}\right]_{0} \leq 6
$$

In all cases the curves:

$$
\frac{1}{\left[\mathrm{C}_{5} \mathrm{H}_{10} \mathrm{NNH}_{2}\right]_{0}-\left[\mathrm{NH}_{2} \mathrm{Cl}\right]_{0}} \log \frac{\left[\mathrm{NH}_{2} \mathrm{Cl}\right]_{0}\left[\mathrm{C}_{5} \mathrm{H}_{10} \mathrm{NNH}_{2}\right]}{\left[\mathrm{C}_{5} \mathrm{H}_{10} \mathrm{NNH}_{2}\right]_{0}\left[\mathrm{NH}_{2} \mathrm{Cl}\right]}=\mathrm{f}(\mathrm{t})
$$


showed to be straight lines with the slope $\mathrm{k}_{2}$, which confirms that $\alpha=\beta=1$ (Figure 5). Consequently, the second order rate constant at $\mathrm{pH}=12.89, \mathrm{~T}=25^{\circ} \mathrm{C}$ was found to be equal to $\mathrm{k}_{2}=18 \times 10^{-3} \pm 0.7 \times 10^{-3} \mathrm{M}^{-1} \mathrm{~s}^{-1}$.

$\log \frac{\left[\mathrm{NH}_{2} \mathrm{Cl}\right]_{0}\left[\mathrm{C}_{5} \mathrm{H}_{10} \mathrm{NNH}_{2}\right]}{\left[\mathrm{C}_{5} \mathrm{H}_{10} \mathrm{NNH}_{2}\right]_{0}\left[\mathrm{NH}_{2} \mathrm{Cl}\right]}$

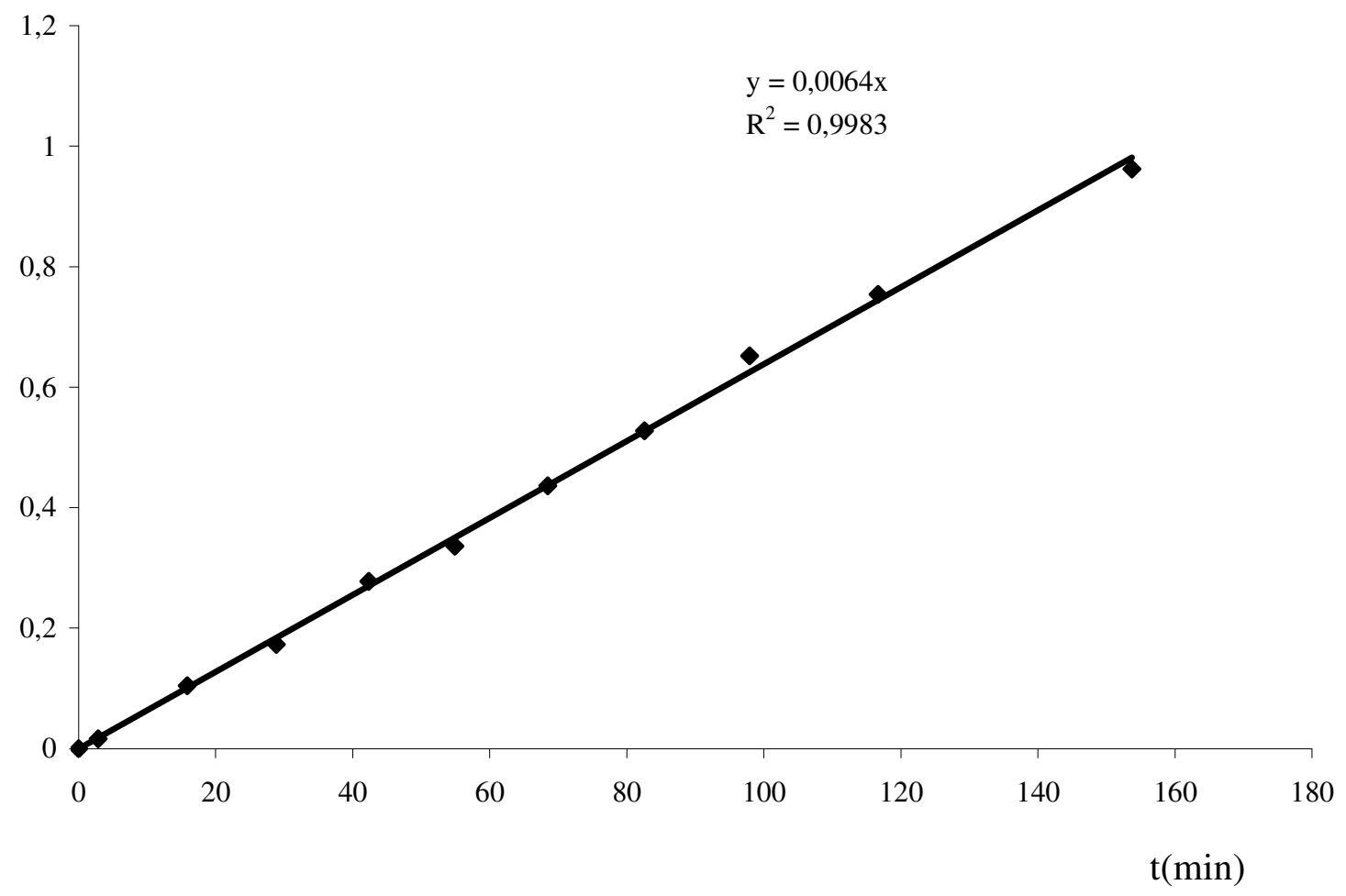

Figure 5. Determination of the kinetic parameters in the oxidation of $\mathrm{N}$ aminopiperidine with chloramine (first step of the reaction monitored by HPLC; $\left.\left[\mathrm{C}_{5} \mathrm{H}_{10} \mathrm{NNH}_{2}\right]_{0}=10 \times 10^{-3} \mathrm{M},\left[\mathrm{NH}_{2} \mathrm{Cl}\right]_{0}=4 \times 10^{-3} \mathrm{M}, \mathrm{pH}=12.89, \mathrm{~T}=25^{\circ} \mathrm{C}\right)$. 


\begin{tabular}{|c|c|c|c|}
\hline$\left[\mathrm{NH}_{2} \mathrm{Cl}\right]_{0}(\mathrm{M})$ & {$\left[\mathrm{C}_{5} \mathrm{H}_{10} \mathrm{NNH}_{2}\right]_{0}(\mathrm{M})$} & $\psi\left(\mathrm{s}^{-1}\right)$ & $\mathrm{k}_{2}\left(\mathrm{M}^{-1} \mathrm{~s}^{-1}\right)$ \\
\hline $1 \times 10^{-3}$ & $10 \times 10^{-3}$ & $1.86 \times 10^{-4}$ & $18.60 \times 10^{-3}$ \\
$1 \times 10^{-3}$ & $20 \times 10^{-3}$ & $3.29 \times 10^{-4}$ & $16.46 \times 10^{-3}$ \\
$1 \times 10^{-3}$ & $30 \times 10^{-3}$ & $5.25 \times 10^{-4}$ & $17.50 \times 10^{-3}$ \\
$1 \times 10^{-3}$ & $40 \times 10^{-3}$ & $7.20 \times 10^{-4}$ & $18.00 \times 10^{-3}$ \\
$1 \times 10^{-3}$ & $50 \times 10^{-3}$ & $8.79 \times 10^{-4}$ & $17.58 \times 10^{-3}$ \\
$1 \times 10^{-3}$ & $60 \times 10^{-3}$ & $1.10 \times 10^{-3}$ & $18.21 \times 10^{-3}$ \\
$1 \times 10^{-3}$ & $100 \times 10^{-3}$ & $1.83 \times 10^{-3}$ & $18.30 \times 10^{-3}$ \\
$2 \times 10^{-3}$ & $30 \times 10^{-3}$ & $5.27 \times 10^{-4}$ & $17.56 \times 10^{-3}$ \\
$3 \times 10^{-3}$ & $30 \times 10^{-3}$ & $5.22 \times 10^{-4}$ & $17.39 \times 10^{-3}$ \\
$4 \times 10^{-3}$ & $30 \times 10^{-3}$ & $5.35 \times 10^{-4}$ & $17.84 \times 10^{-3}$ \\
$5 \times 10^{-3}$ & $10 \times 10^{-3}$ & $*$ & $18.30 \times 10^{-3}$ \\
$5 \times 10^{-3}$ & $15 \times 10^{-3}$ & $*$ & $18.61 \times 10^{-3}$ \\
$5 \times 10^{-3}$ & $20 \times 10^{-3}$ & $*$ & $18.22 \times 10^{-3}$ \\
$5 \times 10^{-3}$ & $30 \times 10^{-3}$ & $*$ & $17.20 \times 10^{-3}$ \\
\hline
\end{tabular}

Table 1. Determination of the partial orders and the rate constant in the oxidation of $N$-aminopiperidine with chloramine $\left(\mathrm{pH}=12.89, \mathrm{~T}=25^{\circ} \mathrm{C}\right)$.

A second series of measurements was performed at $25^{\circ} \mathrm{C}$ in a $\mathrm{pH}$ interval ranging between 12.0 and 13.5 for $1 \leq\left[\mathrm{C}_{5} \mathrm{H}_{10} \mathrm{NNH}_{2}\right]_{0} /\left[\mathrm{NH}_{2} \mathrm{Cl}\right]_{0} \leq 10$ (Table 2). The established rate law (partial orders and stoichiometry) were preserved. Furthermore, $\mathrm{k}_{2}$ remained quite constant at this $\mathrm{pH}$ range with a slight shift towards higher values when the $\mathrm{pH}$ started decreasing.

To interpret the results, it is important to distinguish between two domains where the $\mathrm{pH}$ is above or below 12.89. For $12.0<\mathrm{pH}<12.89, \mathrm{k}_{2}$ was determined at the first reaction instants in the same procedure described for the first series of measurements. Under these conditions, the rate constant value began to increase gradually as $\mathrm{pH}$ went below 12.89 . 
To determine $\mathrm{k}_{2}$ for $\mathrm{pH}$ values above 12.89 , it is necessary to take the alkaline hydrolysis of chloramine into account. This reaction has been studied by several authors [24-30]. The first elementary step corresponds to the formation of a hydroxylamine intermediate (Scheme VII), which immediately reacts producing several compounds $\left(\mathrm{NO}^{-}, \mathrm{N}_{2} \mathrm{O}, \mathrm{N}_{2} \mathrm{O}_{2}{ }^{2-}, \mathrm{ONOO}^{-}\right)$.

\section{Scheme VII}

$$
\mathrm{NH}_{2} \mathrm{Cl}+\mathrm{OH}^{-} \longrightarrow \mathrm{NH}_{2} \mathrm{OH}+\mathrm{Cl}^{-}
$$

This reaction follows a second order rate law:

$$
-\mathrm{d}\left[\mathrm{NH}_{2} \mathrm{Cl}\right] / \mathrm{dt}=\mathrm{k}_{3}\left[\mathrm{NH}_{2} \mathrm{Cl}\right]\left[\mathrm{OH}^{-}\right]
$$

where $\mathrm{k}_{3}=62 \times 10^{-6} \mathrm{M}^{-1} \mathrm{~s}^{-1}$ at $25^{\circ} \mathrm{C}[27]$.

Therefore, we followed simultaneously the disappearances of both reactants based on $[$ FNAPP $]=\mathrm{f}(\mathrm{t})$ and $\left[\mathrm{NH}_{2} \mathrm{Cl}\right]=\mathrm{f}(\mathrm{t})$. By combining the following equations:

$$
-\mathrm{d}[\mathrm{NAPP}] / \mathrm{dt}=\mathrm{k}_{2}\left[\mathrm{NH}_{2} \mathrm{Cl}\right][\mathrm{NAPP}]
$$

$$
\begin{aligned}
-\mathrm{d}\left[\mathrm{NH}_{2} \mathrm{Cl}\right] / \mathrm{dt} & =\mathrm{k}_{2}\left[\mathrm{NH}_{2} \mathrm{Cl}\right][\mathrm{NAPP}]+\mathrm{k}_{3}\left[\mathrm{NH}_{2} \mathrm{Cl}\right]\left[\mathrm{OH}^{-}\right] \\
-\mathrm{d}\left[\mathrm{OH}^{-}\right] / \mathrm{dt} & =\mathrm{k}_{2}\left[\mathrm{NH}_{2} \mathrm{Cl}\right][\mathrm{NAPP}]+\mathrm{k}_{3}\left[\mathrm{NH}_{2} \mathrm{Cl}\right]\left[\mathrm{OH}^{-}\right]
\end{aligned}
$$

an implicit equation, which is a function of instantaneous concentrations of NAPP and $\mathrm{NH}_{2} \mathrm{Cl}$, is obtained and its resolution allowed us to calculate the constant $\mathrm{k}_{2}$ :

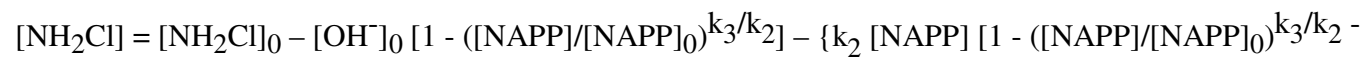

$$
\begin{aligned}
& \left.\left.{ }_{1}\right]\right\} /\left(\mathrm{k}_{3}-\mathrm{k}_{2}\right)
\end{aligned}
$$

The values of $\mathrm{k}_{2}$ for the range $12.0<\mathrm{pH}<13.53$ are given in Table 2 . 


\begin{tabular}{|c|c|c|c|}
\hline$\left[\mathrm{NH}_{2} \mathrm{Cl}\right]_{0}(\mathrm{M})$ & {$\left[\mathrm{C}_{5} \mathrm{H}_{10} \mathrm{NNH}_{2}\right]_{0}(\mathrm{M})$} & $\mathrm{pH}$ & $\mathrm{k}_{2}\left(\mathrm{M}^{-1} \mathrm{~s}^{-1}\right)$ \\
\hline $1 \times 10^{-3}$ & $1 \times 10^{-3}$ & 12.03 & $30.21 \times 10^{-3}$ \\
$1 \times 10^{-3}$ & $5 \times 10^{-3}$ & 12.54 & $25.33 \times 10^{-3}$ \\
$2 \times 10^{-3}$ & $10 \times 10^{-3}$ & 12.70 & $22.75 \times 10^{-3}$ \\
$1 \times 10^{-3}$ & $10 \times 10^{-3}$ & 12.89 & $18.60 \times 10^{-3}$ \\
$1 \times 10^{-3}$ & $1 \times 10^{-3}$ & 13.35 & $18.48 \times 10^{-3}$ \\
$1 \times 10^{-3}$ & $1 \times 10^{-3}$ & 13.53 & $18.14 \times 10^{-3}$ \\
\hline
\end{tabular}

Table 2. Kinetics of the $\mathrm{NAPP}-\mathrm{NH}_{2} \mathrm{Cl}$ interaction. Determination of the rate constant values for $12.0<p H<13.53\left(T=25^{\circ} \mathrm{C}\right)$.

\section{Influence of temperature}

The temperature effect was studied at $\mathrm{pH} 12.89$ between 15 and $45^{\circ} \mathrm{C}$. Concentrations for $\mathbf{1}$ and $\mathrm{NH}_{2} \mathrm{Cl}$ used were equal to $20 \times 10^{-3} \mathrm{M}$ and $2 \times 10^{-3} \mathrm{M}$, respectively. The variation of $k_{2}$ with temperature was found to comply with the Arrhenius law. The curve $\log \mathrm{k}_{2}=\mathrm{f}(1 / \mathrm{T})$ is a straight line of slope $=-\mathrm{E}_{2} / \mathrm{R}$ and $\mathrm{Y}$ intercept $=\log A_{2}\left(r^{2}=0.999\right) . A_{2}$ and $E_{2} / R$ represent the Arrhenius factor and activation energy, respectively.

$$
\mathrm{k}_{2}=1.15 \times 10^{5} \exp (-39 / \mathrm{RT}) \mathrm{M}^{-1} \mathrm{~s}^{-1} \quad\left(\mathrm{E}_{2} \text { in } \mathrm{kJ} \mathrm{mol}^{-1}\right)
$$

The enthalpy and entropy of activation can be deduced from the following formulas:

$$
\Delta \mathrm{H}_{2}{ }^{\circ \neq}=\mathrm{E}_{2}-\mathrm{RT} \text { and } \Delta \mathrm{S}_{2}{ }^{\circ \neq}=\log \left(\mathrm{A}_{2} \mathrm{~h}\right) /\left(\mathrm{e} \mathrm{k}_{\mathrm{B}} \mathrm{T}\right)
$$

where $\mathrm{k}_{\mathrm{B}}$ is Boltzmann's constant and $\mathrm{h}$ is Planck's constant

$\left(\mathrm{k}_{\mathrm{B}}=1.38033 \times 10^{-23} \mathrm{~J} \mathrm{~K}^{-1}, \mathrm{~h}=6.623 \times 10^{-23} \mathrm{~J} \mathrm{~s}\right)$.

The calculated values are:

$$
\Delta \mathrm{H}_{2}{ }^{\circ \neq}=36.52 \mathrm{~kJ} \mathrm{~mol}^{-1} \quad \Delta \mathrm{S}_{2}{ }^{\circ \neq}=-156.3 \mathrm{~J} \mathrm{~mol}^{-1} \mathrm{~K}^{-1}
$$




\section{Mechanism}

The experimental results showed that the reaction between $\mathrm{C}_{5} \mathrm{H}_{10} \mathrm{NNH}_{2}$ and $\mathrm{NH}_{2} \mathrm{Cl}$ consists of two steps, in which the first follows a second order rate law and leads to an aminonitrene $\mathbf{3}$ according to the following redox mechanism [31, 32] (Scheme VIII).

\section{Scheme VIII}

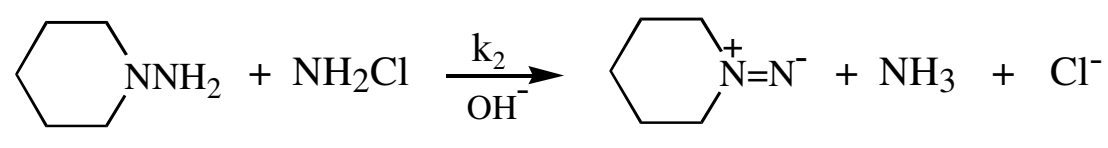

3

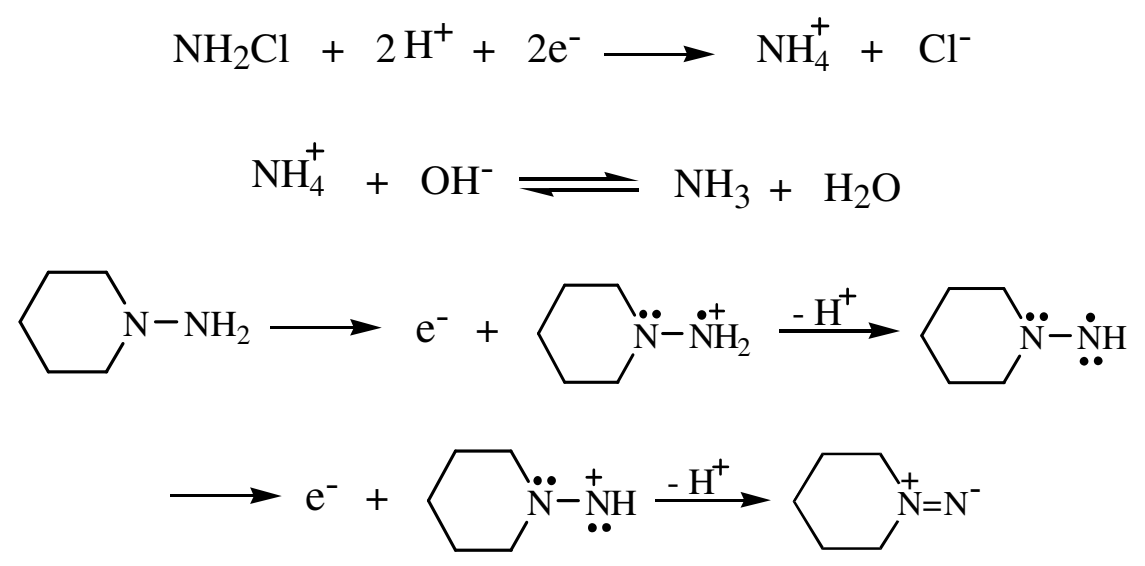

In the second step, $\mathbf{3}$ is converted to different compounds depending on experimental conditions. However, GC/MS (Figure 2) analyses of different reaction mixtures (conducted under different conditions) revealed identical results with the only variation of the peaks' intensities ratios. From this observation, the following conclusions can be drawn:

- With increasing $\mathrm{pH}$, peak $\mathbf{d}$ increases its intensity. Hence, $\mathbf{d}$ might correspond to a hydrazone (1,2-diazacyclohept-1-ene) obtained by an intramolecular rearrangement of aminonitrene. The latter is responsible for the absorption at $237 \mathrm{~nm}$ appearing at the end of the second step in the experiments conducted at $\mathrm{pH} \geq 12$. This conclusion 
agrees with previous studies on the rearrangement aminonitrene - hydrazone described in Scheme IX [33].

Scheme IX

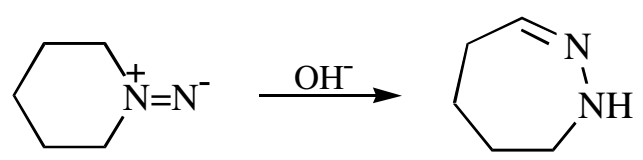

d
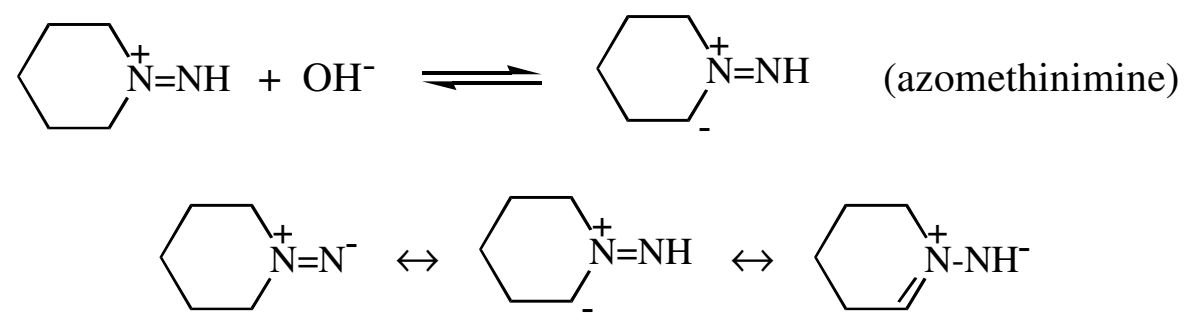

(diaziridine)
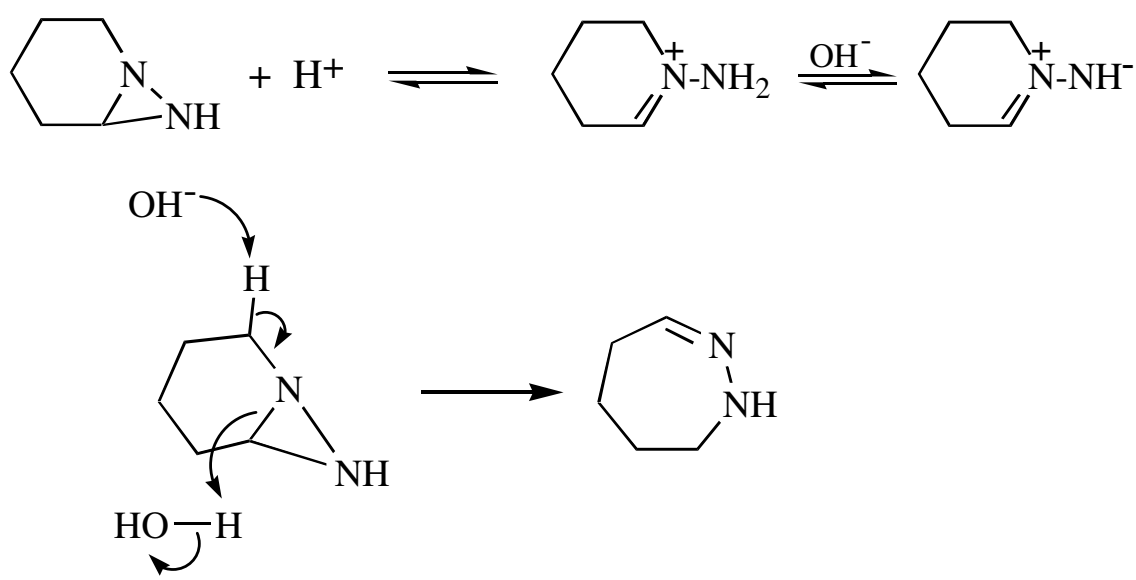

- Two peaks $\mathbf{h}$ and $\mathbf{i}$ of same $\mathrm{m} / \mathrm{z}=196$ were also observed and their intensities showed to be more important when the concentration of chloramine is higher (the ratio $\frac{[196]+[196]}{[98]}$ increases with $\left.\left[\mathrm{NH}_{2} \mathrm{Cl}\right]_{0}\right) . \mathbf{h}$ and $\mathbf{i}$ correspond to two tetrazine compounds, namely azopiperidine and dipyridododecahydro-s-tetrazine both resulting from diazene according to Scheme $\mathrm{X}$. The suggested mechanism agrees with Figures 3 and 4, showing UV absorptions of the reaction mixture for experiments conducted at lower $\mathrm{pH}$ : At $\mathrm{pH}=11$ (Figure 4), UV spectra are mainly due to the azopiperidine absorption. 
Scheme X

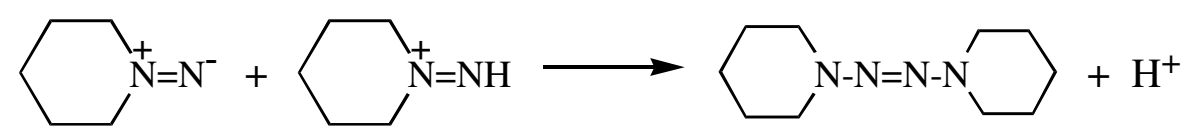

Azopiperidine $(\mathrm{m} / \mathrm{z}=196)$

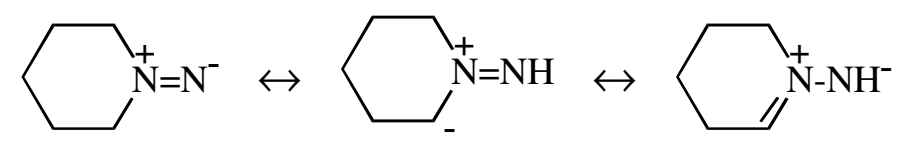

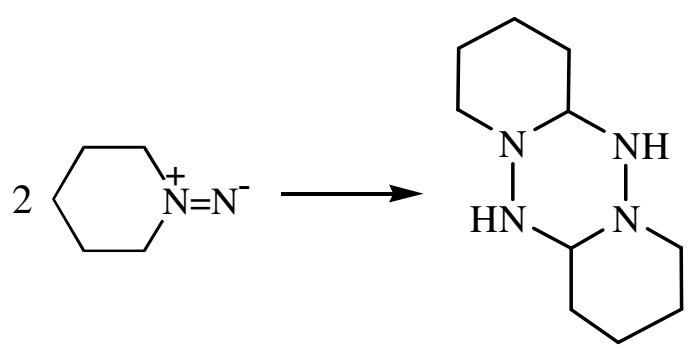

Dipyridododecahydro-s-tetrazine $(\mathrm{m} / \mathrm{z}=196)$

- By studying the possible evolution routes of the two reactants, it was proven that the other peaks observed cannot be related to diazene. They are consequent upon a succeeding reactional chain based on the evolution of 1-piperidine (peak a) present as an impurity in the starting material (peak b) and also resulting from the oxidation of NAPP with air: first it formed 1-nitrosopiperidine (peak c) which is converted into 1-piperidine. The latter is responsible for the numerous peaks observed in GC/MS. A complete characterization of the compounds obtained will be topic of further investigations.

\section{Acknowledgements}

We are grateful to ISOCHEM (groupe SNPE) for financial support. C. D. would like to thank the Centre National Français de la Recherche Scientifique for the $\mathrm{PhD}$ scholarship and Monsieur Antoine OLLAGNIER for valuable help in Figures 
editing. The Claude Bernard University of Lyon and the Lebanese University are also gratefully acknowledged.

\section{References}

[1] Wright, J.B. and Willette, R.E., J. Med. Pharm. Chem., 1962, vol. 5, p. 815.

[2] Hanna, C. and Schueler, F.W., J. Am. Chem. Soc., 1952, vol. 74, p. 3693.

[3] Fr Patent 1400256.

[4] Smith, P.A.S. and Pars, H.G., J. Org. Chem., 1959, vol. 24, p. 1325.

[5] Lunn, G., Sansone, E.B. and Keefer, L.K., J. Org. Chem., 1984, vol. 49, p. 3470.

[6] Podgornaya, I.V., Tayusheva, N.N. and Postovskii, I.Y., Zhurnal Obshchei Khimii, 1964, vol. 34, p. 2521.

[7] Allen \& Hanburys, NL Patent 6510107, 1966.

[8] Laboratoire Lafon, Be Patent 812749, 1974.

[9] Latourette, H. K. and Pianfetti, J. A., US Patent 3317607, 1967.

[10] Tuemmler, W. B. and Winkler, H. L. S., US Patent 2979505, 1961.

[11] Lima, D. A., US Patent 3154538, 1964.

[12] Zimmer, H., Audrieth, L.F., Zimmer, M. and Rowe, R.V., J. Am. Chem. Soc., 1955, vol. 77 , p. 790.

[13] Ohme, R. and Preuschhof, H., Ger (east) Patent 76520, 1970.

[14] Ohme, R. and Preuschhof, H., J. Prakt. Chem., 1970, vol. 312, p. 349.

[15] Murakami, Y., Yokoyama, Y., Sasakura, C. and Tamagawa, M., Chem. Pharm. Bull., 1983, vol. 31, p. 423.

[16] Ohme, R. and Preuschhof, H., Liebigs Ann. Chem., 1968, vol. 713, p. 74.

[17] Hasegawa, Y., Hyoda, S., Fujita, H., Sawada, H. and Oki, Y., Eur. Patent 850930, 1998. 
[18] Sumitani, H. and Matsui, N., Jp Patent 183250, 2003.

[19] Raschig, F., Chem. Ztg., 1907, vol. 31, p. 926.

[20] Raschig, F., Ber. Dtsch. Chem. Ges., 1907, vol. 40, p. 4580.

[21] Darwich, C., Dissertation, Lyon: Université Lyon I, 2005.

[22] Ferriol, M., Gazet, J. and Rizk-Ouaini, R., Anal. Chim. Acta, 1990, vol. 231, p. 161.

[23] Elkhatib, M., Peyrot, L., Scharff, J.P. and Delalu, H., Int. J. Chem. Kinet., 1998, vol. 30, p. 129.

[24] Elkhatib, M., Marchand, A., Counioux, J.J. and Delalu, H., Int. J. Chem. Kinet., 1995, vol. 27, p. 757.

[25] Delalu, H., Dissertation, Lyon : Université Lyon I, 1977.

[26] Anbar, M. and Yagil, G., J. Am. Chem. Soc., 1962, vol. 84, p. 1790.

[27] Yagil, G. and Anbar, M., J. Inorg. Nucl. Chem., 1964, vol. 26, p. 453.

[28] McCoy, R.E., J. Am. Chem. Soc., 1954, vol. 76, p. 1447.

[29] Lenoble, W.J., Tetrahedron Lett., 1966, vol. 7, p. 727.

[30] Elkhatib, M., Duriche, C., Peyrot, L., Metz, R. and Delalu, H., Int. J. Chem. Kinet., 2002, vol. 34, p. 515.

[31] Lemal, D.M., Nitrenes. In: Nitrenes, New York: Lwowski edition, Interscience, 1970.

[32] Schmidt, E.W., Hydrazine and its derivatives, preparation, properties, application, New York: Wiley, 1984.

[33] Peyrot, L., Elkhatib, M., Vignalou, J.R., Metz, R., Elomar, F. and Delalu, H., J. Het. Chem., 2001, vol. 38, p. 885. 